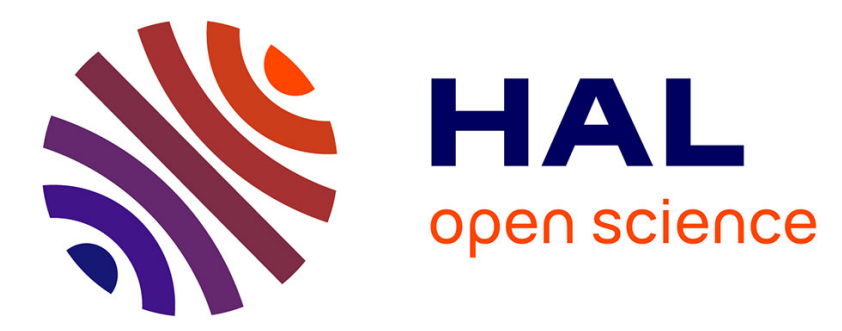

\title{
Distribution of trace elements in the tissues of benthic and pelagic fish from the Kerguelen Islands
}

\author{
Paco Bustamante, Pierrick Bocher, Yves Cherel, Pierre Miramand, Florence
} Caurant

\section{- To cite this version:}

Paco Bustamante, Pierrick Bocher, Yves Cherel, Pierre Miramand, Florence Caurant. Distribution of trace elements in the tissues of benthic and pelagic fish from the Kerguelen Islands. Science of the Total Environment, 2003, 313 (1-3), pp.25-39. 10.1016/S0048-9697(03)00265-1 . hal-00186633

\section{HAL Id: hal-00186633 https://hal.science/hal-00186633}

Submitted on 10 Nov 2007

HAL is a multi-disciplinary open access archive for the deposit and dissemination of scientific research documents, whether they are published or not. The documents may come from teaching and research institutions in France or abroad, or from public or private research centers.
L'archive ouverte pluridisciplinaire HAL, est destinée au dépôt et à la diffusion de documents scientifiques de niveau recherche, publiés ou non, émanant des établissements d'enseignement et de recherche français ou étrangers, des laboratoires publics ou privés. 


\section{Distribution of trace elements in the tissues of benthic and pelagic fish from the Kerguelen Islands}

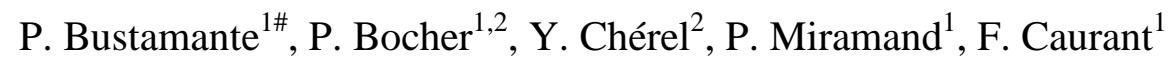

${ }^{1}$ Laboratoire de Biologie et Environnement Marins, UPRES-EA 3168, Université de La Rochelle, 22, Avenue Michel Crépeau, F-17042 La Rochelle Cedex, France

${ }^{2}$ Centre d'Etudes Biologiques de Chizé, UPR 4701 du Centre National de la Recherche Scientifique, F-79360 Villiers-en-Bois, France

\# Corresponding author: Dr. Paco Bustamante

Laboratoire de Biologie et Environnement Marins
UPRES-EA 3168
Université de La Rochelle
22, Avenue Michel Crépeau
F-17042 La Rochelle (France)
Tel.: (+33) 546500294
Fax: (+33) 546500294
e-mail: pbustama@univ-lr.fr

Abstract: New information on the concentrations of $\mathrm{Cd}, \mathrm{Cu}, \mathrm{Hg}$ and $\mathrm{Zn}$ in the liver, kidney and muscles of 8 marine benthic and pelagic sub-Antarctic fish species are presented to determine the importance of these metals in the marine systems of the Kerguelen Islands. Compared to the reported metal concentrations in other Antarctic fish species, the present results are globally within the same range of concentrations, although $\mathrm{Cd}$ displayed a very high interspecific variability in liver and kidney. Indeed, the highest Cd concentrations in liver, ranging from 10.0 to $52.1 \mu \mathrm{g} . \mathrm{g}^{-1}$ dry wt but also the lowest $\mathrm{Cd}$ concentrations in muscles $\left(<0.030 \mu \mathrm{g} . \mathrm{g}^{-1}\right.$ dry wt) have been displayed by the pelagic Myctophidae Gymnoscopelus piabilis. Metal concentrations differences might be related to diet and feeding habits of benthic and pelagic fish species. However, $\mathrm{Cd}$ and $\mathrm{Hg}$ concentrations in the edible muscle are lower than the French limit values $\left(\leq 0.155 \mu \mathrm{g} \mathrm{Cd} \mathrm{g}^{-1}\right.$ dry wt and $\leq 1.51 \mu \mathrm{g} \mathrm{Hg} \mathrm{g}^{-1}$ dry wt) for these toxic metals as well as for edible and non-commercially interesting fish species. Results for $\mathrm{Cd}$ in fish tissues are consistent with the hypothesis of $\mathrm{Cd}$-enrichment in the polar food webs typically explained by essential elements depletion. In fact, Zn concentrations in fish from the Kerguelen Islands are comparable to those of other areas but low $\mathrm{Cu}$ concentrations 
in fish livers, ranging from 0.9 to $24.7 \mu \mathrm{g} \cdot \mathrm{g}^{-1}$ dry wt, might indicate low availability of this essential element in these sub-Antarctic waters.

Keywords : Antarctic ; Heavy metals ; Cd-enrichment ; Myctophidae

\section{INTRODUCTION}

Heavy metal concentrations in the organisms from the Austral Ocean have been globally poorly investigated. However, all the studies report high toxic metal concentrations, especially for $\mathrm{Cd}$ and $\mathrm{Hg}$, in comparison with those from northern temperate waters. Such metals enrichment have been reported for polar areas (AMAP 1998, Petri and Zauke 1993, Sanchez-Hernandez 2000) but in the Antarctic and sub-Antarctic food webs, it remains unclear even if the extreme environmental conditions (e.g. temperature, seasonal alternation, essential elements availability) might play a key role on the processes of uptake, storage and elimination of the metals by organisms. Moreover, local environmental factors such as volcanism or upwellings could increase metal concentrations in the marine environment.

Specifically, in the Kerguelen Islands environment, high concentrations of $\mathrm{Cd}$ have been found to occur in 2 species of benthic octopuses (Bustamante et al. 1998). Generally, cephalopods are known to strongly accumulate $\mathrm{Cd}$ in their digestive gland but the concentrations reported for the Kerguelen octopuses were particularly high. Such high Cd levels have also been reported for some Antarctic zooplankton species as a likely result of very low essential elements availability to these organisms (Rainbow 1989, Petri \& Zauke 1993). The Cd enrichment in the zooplankton cannot be fully considered as the direct result of anthropogenic contamination owing to the very low levels reported for other zooplankton species living in the same waters (see the data compiled by Sanchez-Hernandez 2000).

Several studies report metal concentrations in the tissues of 13 fish species of various Antarctic areas (Honda et al. 1983, Lenihan et al. 1990, Capelli et al. 1991, Szefer et al. 1993, Minganti et al. 1994, 1995, Bargagli et al. 1996, 1998ab, de Moreno et al 1997, Marquez et al. 1998). However, no data for the fish from the Kerguelen Islands are available to date. This sub-Antarctic Archipelago is of a great ecological interest since millions of seabirds and numerous marine mammals breed there every year (Guinet et al. 1996). Furthermore, as in many sub-Antarctic areas, commercial fisheries developped at the end of the 60s, targetting fish of the families Nototheniidae and Channichthyidae (Duhamel \& Hureau 1981). Thus, 
baseline information on heavy metal concentrations in the tissue of fish are needed in order to evaluate the fish quality for human consumption as well as for piscivorous predators.

For these reasons, selected heavy metals have been analysed in the liver, kidney and muscles of several fish species, including benthic (neritic) and pelagic (oceanic) ones. Thus, 35 specimens representing 8 different species from the Kerguelen Island waters have been individually analysed for each $\mathrm{Cd}, \mathrm{Cu}, \mathrm{Hg}$ and $\mathrm{Zn}$ contents. Metal concentrations and tissue distribution, are compared between species from different Antarctic areas, and influence of the diet of benthic and pelagic species on the accumulation are discussed.

\section{MATERIALS AND METHODS}

Sampling and sample preparation

Pelagic fish were collected on cruises of the RV "La Curieuse" during austral summer. Myctophidae and Gempylidae were caught in the eastern part of the peri-insular shelf in February 1998, using a IYGPT trawl (International Young Gadoid Pelagic Trawl, opening 12 $\mathrm{X} 7 \mathrm{~m}$ ) with $10 \mathrm{~mm}$ mesh size in the cone.

Benthic fish were captured either by net fishing overnight in the Morbihan Bay (Notothenia rossii and Paranotothenia magellanica) or by commercial trawling on the Kerguelen shelf (Channichthys rhinoceratus, Chamsocephalus gunnari and Lepidonotothen squamifrons) (Table 1).

The fish were separated by species and stored on board at $-20^{\circ} \mathrm{C}$ in plastic bags prior to analysis. Subsequently, the length, weight and sex of fish were determined. Moreover, otoliths of Myctophidae species were taken out to ensure identification of the species. Then, specimens were dissected and liver, kidney and muscle tissues were treated separately. The remainders of each dissected individual were also analysed individually in view of determining the percentage distribution of the metals. Characteristics of the samples (i.e. family, species, length, weight and sex) are shown in Table 1.

\section{Analytical procedure}

Separated tissue samples were dried to a constant weight for several days at $60^{\circ} \mathrm{C}$ and then homogenised. Whenever possible, 2 aliquots of approx. $300 \mathrm{mg}$ of each homogenised dry 
sample were digested with $5 \mathrm{ml}$ of $65 \% \mathrm{HNO}_{3}$ and $0.3 \mathrm{ml}$ of $70 \% \mathrm{HClO}_{4}$ at $80^{\circ} \mathrm{C}$ for $24 \mathrm{~h}$. The residues obtained after evaporation of the acids were dissolved in $0.3 \mathrm{~N}$ nitric acid. $\mathrm{Cd}$, $\mathrm{Cu}$ and $\mathrm{Zn}$ were assayed using flame and graphite furnace atomic absorption spectrophotometer Varian 250 Plus with deuterium background correction.

For $\mathrm{Hg}$, aliquots ranging from 10 to $50 \mathrm{mg}$ of dried material have been analysed directly in a Advanced Mercury Analyser spectrophotometer, Altec AMA 254. Hg determination involved evaporation of $\mathrm{Hg}$ by progressive heating until $800^{\circ} \mathrm{C}$ under oxygen atmosphere for $3 \mathrm{~min}$ and subsequent amalgamation on a Au-net. Afterwards, the net was heated to liberate the collected mercury and subsequently measured by UV atomic absorption spectrophotometry. However, $\mathrm{Hg}$ analysis were not performed in the liver and kidney of the pelagic fish nor for Lepidonotothen squamifrons.

Quality assurance was assessed using dogfish liver DOLT-2 (NRCC) and dogfish muscle DORM-2 (NRCC) as reference materials. These standards were treated and analysed under the same conditions as the fish samples, and recoveries of the metals ranged from 92 to $105 \%$. Detection limits, calculated as $3 \mathrm{SD}$ of the mean of eight blanks, were 0.004 for $\mathrm{Cd}, 0.5$ for $\mathrm{Cu}, 3$ for $\mathrm{Zn}$ and 0.005 for $\mathrm{Hg}\left(\mu \mathrm{g} \cdot \mathrm{g}^{-1}\right.$ dry wt). All metal concentrations in fish tissues are also reported in $\mu \mathrm{g} . \mathrm{g}^{-1}$ dry wt. Water contents allowing recalculations of the metal concentrations from dry wt to wet wt are given in Table 1 .

Statistical procedures

Statistically analysis of results used commercially available packages. As concentration of some elements did not follow a normal distribution, non parametric analysis using KruskallWallis test for multiple comparisons and Mann-Whitney U-test provided by Minitab 13.1 for Windows. A statistically significant difference was considered to exist whenever the probability is lower than $\mathrm{P} \leq 0.05$.

\section{RESULTS}

Results on heavy metal concentrations in the tissues of fish from the Kerguelen Islands are compiled in Tables 2, 3 and 4 for liver, kidney and muscle, respectively.

In liver, metal concentrations exhibited a large variability among species. For $\mathrm{Hg}$, concentrations differ in 2 orders of magnitude, i.e. between 0.042 and $1.51 \mu \mathrm{g} \cdot \mathrm{g}^{-1}$ dry wt. The Myctophidae Gymnoscopelus piabilis and the Notothenidae Lepidonotothen squamifrons 
showed significantly higher $\mathrm{Cd}$ and $\mathrm{Zn}$ concentrations in liver. For $\mathrm{Cu}$ and $\mathrm{Zn}$, Paranotothenia magellanica also exhibited the highest concentrations. Among the 3 organs considered, liver displays the highest $\mathrm{Cd}$ and $\mathrm{Cu}$ concentrations. Compared to muscle, hepatic $\mathrm{Cd}$ concentrations are 2 to 4 orders of magnitude higher whereas $\mathrm{Cu}$ concentrations are only 2 to 10 times higher (Table 2).

Despite the heterogeneity of metal concentrations in liver, no clear segregation between pelagic and benthic fish could be done. This was also the case for kidney. Compared to muscle, kidney shows elevated concentrations of $\mathrm{Cd}$ and $\mathrm{Cu}$. Among the 3 tissues, kidney had the highest $\mathrm{Zn}$ but the lowest $\mathrm{Hg}$ concentrations. As in liver, the Myctophidae Gymnoscopelus piabilis and the Notothenidae Lepidonotothen squamifrons exhibited significantly higher renal $\mathrm{Cd}$ concentrations compared to the other fish species. Renal $\mathrm{Cu}$ concentrations were significantly elevated only for G. piabilis (Table 3).

Compared to the results for liver and kidney, $\mathrm{Cd}, \mathrm{Cu}$ and $\mathrm{Zn}$ concentrations appeared to be low in fish muscles although the important variability among species is remarkable (Table 4). Muscular $\mathrm{Cd}$ and $\mathrm{Zn}$ concentrations were generally lower in pelagic fish than in benthic ones. Similarly, mean $\mathrm{Hg}$ concentrations varied on 3 orders of magnitude in the muscle (from 0.044 to $1.19 \mu \mathrm{g} \cdot \mathrm{g}^{-1}$ dry wt) in both benthic and pelagic fish. Nevertheless, the Channichthydae Channichthys rhinoceratus exhibited clearly the highest $\mathrm{Hg}$ concentrations (Table 4).

Complete dissection of fish allowed to calculate the distribution of metals between liver, kidney (representing less than $5 \%$ and than $1 \%$ of the whole body mass) and the remaining tissue including muscle. The percentage of each metal contained in these compartments is shown in Table 5.

$\mathrm{Cd}$ and $\mathrm{Cu}$ concentrations displayed the same distribution pattern in the tissues of benthic and pelagic fish: liver > kidney > muscle. Despite several orders of magnitude between $\mathrm{Cd}$ concentrations in muscle and liver, the latter generally contained less than $50 \%$ of the total body burden of $\mathrm{Cd}$. Thus, most of this $\mathrm{Cd}$ was muscular except for the Channichthydae Channichthys rhinoceratus (87\% of Cd located in liver; Table 5). Owing to the small differences between muscle and liver $\mathrm{Cu}$ concentrations and to the respective proportions of these tissues in the fresh weight of fish, less than $20 \%$ of the metal was stored in the hepatic compartment (Table 5).

Zn concentrations showed the following sequence : kidney $>$ liver $>$ muscle but the two first organs contained less than $15 \%$ of the total body burden of $\mathrm{Zn}$. 
Although no clear differences of concentrations between the three tissues appears, the muscular parts of fish contained up to $90 \%$ of the total body burden of $\mathrm{Hg}$ due to its significance (Table 5).

\section{DISCUSSION}

\section{Levels of trace metals}

Despite the past and present human fishing pressure on some of the Austral Ocean areas and their major role in the ecosystems (Guinet et al. 1996, Cherel et al. 2000), data on metal levels in the fish still lacks. Such assessment is particularly true for the sub-antarctic zone while Antarctic Ocean is more documented. Thus, this study represent the first investigation concerning the distribution of trace elements in the tissue of 8 fish species from the subAntarctic Kerguelen Islands. A recent review of trace element contamination around Antarctica (Sanchez-Hernandez 2000) allows to compare the present results with those of several fish species from the Antarctic Ocean.

Overall, the present results about metal concentrations in the tissues of benthic and pelagic fish from the Kerguelen Islands waters fall within the range for the other fish species from the Antarctic Ocean (data compiled in Table 6-8). Reported data for fish liver (Table 6) range from 0.86 to $21.6 \mu \mathrm{g} \mathrm{Cd} \mathrm{g}^{-1}$, from 3.3 to $92 \mu \mathrm{g} \mathrm{Cu} \mathrm{g}^{-1}$, from 0.02 to $0.82 \mu \mathrm{g} \mathrm{Hg} \mathrm{g}^{-1}$ and from 87.7 to $106 \mu \mathrm{g} \mathrm{Zn} \mathrm{g}^{-1}$ (values are expressed in dry wt after conversion from wet wt for some data using a 4.0 correction factor). Generally, the heavy metal levels in fish liver from the Kerguelen Islands tended to be slightly higher than those reported in the current litterature (Table 6), except for $\mathrm{Hg}$ which is closely in the same concentration range.

Concerning kidney, data for Antarctic fish are rarely reported (Table 7). They range from 0.17 to $10.1 \mu \mathrm{g} \mathrm{Cd} \mathrm{g}^{-1}$, and from 0.09 to $2.60 \mu \mathrm{g} \mathrm{Hg} \mathrm{g}^{-1}$ (dry wt) while the only values reported for $\mathrm{Cu}$ and $\mathrm{Zn}$ concern two benthic species, i.e. Notothenia coriiceps (Marquez et al. 1998) and Trematomus bernacchii (Bargagli et al. 1998b). Despite such few data, it also appears that several fish species from the Kerguelen Islands show higher heavy metal concentrations in the kidney compared to other Antarctic fish species. More fish muscle values from the Antarctic Ocean are available (Table 7). Thus, our results are closely within the same range of the reported data: from 0.01 to $1.0 \mu \mathrm{g} \mathrm{Cd} \mathrm{g}^{-1}$, from 0.2 to $2.5 \mu \mathrm{g} \mathrm{Cu} \mathrm{g}^{-1}$, from 0.01 to $1.79 \mu \mathrm{g} \mathrm{Hg}$ $\mathrm{g}^{-1}$, and from 2.0 to $125 \mu \mathrm{g} \mathrm{Zn} \mathrm{g}{ }^{-1}$ (values are expressed in dry wt after conversion from wet wt for some data using a 5.0 correction factor). Considering the French limit value for human consumption of toxic metals, i.e. $0.5 \mu \mathrm{g} \cdot \mathrm{g}^{-1}$ for $\mathrm{Cd}$ and $2.5 \mu \mathrm{g} \cdot \mathrm{g}^{-1}$ for $\mathrm{Hg}$ (CSHPF, 1995), 
metal concentrations in fish muscles appear to be low, as well for the commercially fished species like Channichthys rhinoceratus, Champsocephalus gunnari and Notothenia rossii, than for the other species presented here.

Heavy metals investigations in fish mainly consider concentrations in muscle and/or in liver, in detriment of gills or kidney as well. Furthermore, little information concerning metal distribution has been reported especially for the Antarctic fish. For this reason, comparison with fish outside the Austral Ocean was necessary and revealed that metal distribution in the tissues of Austral Ocean fish is very similar to that of fish from the temperate waters (Miramand et al. 1991).

\section{Interferences on routes of metal uptake}

The very low $\mathrm{Cd}$ concentrations in the muscle of most of the fish species investigated (including Myctophidae) suppose effective processes of Cd sequestration in liver and kidney and demonstrate that dietary uptake of $\mathrm{Cd}$ is likely to be the most important route of assumption in Kerguelen Islands fish. Enrichment of cadmium in liver and kidney with respect to muscles is particularly evident for zooplankton-eating fish, such as Myctophidae (Hulley 1990). Thus, these species from the Kerguelen Islands displayed the highest Cd concentrations in liver and kidney, i.e. from 10.0 to $52.1 \mu \mathrm{g} . \mathrm{g}^{-1} \mathrm{dwt}$ in Gymnoscopelus piabilis compared to 0.86 to $21.6 \mu \mathrm{g} . \mathrm{g}^{-1} \mathrm{dwt}$ in the liver of the species from other areas (Table 6). The diet of Gymnoscopelus consists of crustaceans plankton including euphausiids and euphausiid larvae, hyperiids, and mysids (Hulley 1990). Some of these planktonic species from the Austral Ocean (e.g. euphausiids) exhibit relatively high levels of $\mathrm{Cd}$ for crustaceans, with values ranging from 0.15 to $3.4 \mu \mathrm{g} . \mathrm{g}^{-1} \mathrm{dwt}$ in the krill Euphausia superba (Rainbow 1989, Petri \& Zauke 1993). However, some other planktonic species could reach extremely high levels of Cd like the hyperiid amphipod Themisto gaudichaudii, which concentrate the metal from 8.0 to $118 \mu \mathrm{g} . \mathrm{g}^{-1} \mathrm{dwt}$ (Hennig et al. 1985, Rainbow 1989). Similarly to those reported

results, T. gaudichaudii show very high Cd concentrations ranging from 21.2 to $81.7 \mu \mathrm{g} . \mathrm{g}^{-1}$ dwt in the Kerguelen Island waters (Bustamante, unpublished data). Thus, the high Cd levels recorded in the kidney and liver of G. piabilis would be a direct result of a Cd-rich diet. On the contrary, fish species having the lowest Cd concentrations in their tissues, e.g. Notothenia rossii or Paranotothenia magellanica, are benthic feeders, and include algae, polychaetes, crustaceans, gastropods and fish in their diet (Gon \& Heemstra 1990). However, the 
Trematomus fish which are typical benthic feeders of the Antarctic Ocean, exhibit relatively high values reaching 21.6 and $10.1 \mu \mathrm{g} \mathrm{Cd} \mathrm{g}^{-1}$ in their liver and kidney, respectively (Tables 6 \& 7). This difference can be due to a substantial heterogeneity of age. Thus, these benthic species, as $N$. rossii and P. magellanica used in our study were juveniles (less than 4 years old) while Trematomus were supposed to be adults after length measurements as suggested by Gon \& Heemstra (1990).

\section{Interference on the origin of the metals}

Elevated Cd concentrations in the biota from the Austral Ocean were surprinsingly high for this area remote from human activities. However, except in some localised spots, anthropogenic Cd contamination does not occur in the Austral Ocean, suggesting that the high concentrations found in the examined marine species are essentially due to natural conditions. Thus, the elevated concentrations of this toxic element in both benthic and pelagic invertebrates seem to correpond to $\mathrm{Cd}$-abnormalities in polar waters as inferred for crustaceans and molluscs (Petri \& Zauke 1993, Bargagli et al. 1996, de Moreno et al. 1997, Ritterhoff \& Zauke 1997, Bustamante et al. 1998, Sanchez-Hernandez 2000). Indeed, the low $\mathrm{Cd}$ concentrations in fish muscle indicate low artificial contamination but the elevated $\mathrm{Cd}$ concentrations in both liver and kidney highlight exposure of the fish to the metal. Thus, the high Cd levels in liver and kidney of several Antarctic fish species is a matter of concern.

As it occurs for the Arctic fish (MacDonald \& Sprague 1988, Hellou et al. 1992, Zauke et al. 1999), bioaccumulation of $\mathrm{Cd}$ in the fish from the Austral Ocean is difficult to explain since the $\mathrm{Cd}$ concentrations in the sea water from polar regions are low. Nevertheless, the occurrence of upwelling of deep waters in the Kerguelen region (Plancke 1977) should bring an enrichment of $\mathrm{Cd}$ in the surface waters. The increase of $\mathrm{Cd}$ bioavailability in the Kerguelen Island waters by upwelled deep waters might be at the origin of an increase of $\mathrm{Cd}$ concentrations in the marine biota on a local scale, as discussed for benthic octopus from this area (Bustamante et al. 1998). On the other hand, Bucciarelli et al. (2001) found an iron enrichment of the coastal waters of the Kerguelen Islands and explained it in terms of direct inputs of terrestrial material, as a consequence of riverine discharge, soil leaching by rainwater and aeolian input by strong winds, but also by inputs from the sediments due to effluxes from the sediment at the water interface and resuspension from the sediment. However, our results for $\mathrm{Cd}$ but also for $\mathrm{Cu}, \mathrm{Hg}$ and $\mathrm{Zn}$ in the tissue of Kerguelen Islands fish do not show an enrichment following the same processes as Fe. Indeed, Cd concentrations in 
both liver and kidney of fish caught in close coastal waters (i.e. Notothenia rossii and Paranotothenia magellanica) are the lowest among the 8 studied species. Similarly to fish, metal concentrations in crustaceans also distinguish the coastal samples from the continentalshelf ones. For example, the hyperiid amphipod Themisto gaudichaudii display $\mathrm{Cd}$ concentrations from 21.2 to $27.3 \mu \mathrm{g} . \mathrm{g}^{-1} \mathrm{dwt}$ in the coastal waters (Morbihan Gulf) while 68.2 to $80.7 \mu \mathrm{g} \mathrm{Cd} . \mathrm{g}^{-1} \mathrm{dwt}$ were found in the individuals from the shelf (unpublished data). These new findings point out the necessity to investigate carefully the metal concentrations, particularly for $\mathrm{Cd}$, in the waters surrounding Kerguelen Islands, to determine the sources to biota in this area.

Cd enrichment in marine animals from the Austral Ocean was also proposed to occur for organisms suffering essential elements deficiency, which have evolved very efficient mechanisms of elemental uptake (Petri \& Zauke 1993). However, these mechanisms are probably non specific to the essential metal and so, $\mathrm{Cd}$ might be absorbed by the same pathways than elements like $\mathrm{Cu}$ or $\mathrm{Zn}$. $\mathrm{Zn}$ deficiency is not evident in the Kerguelen Island waters as its concentrations in fish tissues from this area are of the same order than concentrations reported for fish from various areas (Hellou et al. 1992, Roméo et al. 1999, Zauke et al. 1999). Similarly to fish, $\mathrm{Zn}$ concentrations found in the digestive gland of octopus from the Kerguelen Islands are of the same order compared to other cephalopod species (Bustamante et al. 1998). As for Cd, Zn could also be carried by upwelled waters, becoming more available in this area than in open Ocean where upwellings do not occur. Contrarily to $\mathrm{Zn}$, low concentrations of $\mathrm{Cu}$ in the liver of fish from the Kerguelen Islands might be due to a low availability of this element. Indeed, $\mathrm{Cu}$ concentrations appear to be under close physiological regulation in most species (Thompson 1990). In the same way, low $\mathrm{Cu}$ concentrations were also found in octopus from Kerguelen Islands compared to data reported for other cephalopods.

\section{CONCLUSION}

The present work provides new information on the distribution of heavy metals in fish from the Kerguelen Islands. Considering the muscle, concentrations of $\mathrm{Cd}$ and $\mathrm{Hg}$ in both benthic and pelagic species are below the values fixed as a limit by the CSHPF (1995). On the other hand, liver and kidney display very high Cd consequently to high exposure through diet, but very low hepatic $\mathrm{Cu}$ concentrations. This is in accordance with the hypothesis of $\mathrm{Cd}$ enrichment related to $\mathrm{Cu}$ deficiency. In this context, studies on the detoxification and storage 
processes of $\mathrm{Cd}$ in the liver and kidney of Kerguelen Islands fish should be thoroughly carried out.

Acknowledgements. We thank Guy Duhamel and the crew of the RV "La Curieuse" for their help in the collection of the fish specimens. This work was financially supported by the "Conseils Généraux des Deux-Sévres et de la Charente Maritime", and by the Institut Français pour la Recherche et la Technologie Polaires and the Terres Australes et Antarctiques Françaises.

\section{REFERENCES}

AMAP. AMAP Assessment Report: Arctic Pollution Issues. Chapter 7: Heavy metals. Arctic Monitoring and Assessment Programme (AMAP), Oslo, Norway, 1998.

Bargagli R, Nelli L, Ancora S, Focardi S. Elevated cadmium accumulation in marine organisms from Terra Nova Bay (Antarctica). Polar Biol 1996; 16: 513-520.

Bargagli R, Monaci F, Sanchez-Hernandez JC, Cateni D. Biomagnification of mercury in an Antarctic marine food web. Mar Ecol Prog Ser 1998a; 169: 65-76.

Bargagli R, Carsolini S, Fossi MC, Sanchez-Hernandez JC, Focardi S. Antarctic fish Trematomus bernacchii as biomonitor of environmental contaminants at Terra Nova Bay Station (Ross Sea). Mem Natl Insdt PolarRes, Spec Issue 1998b; 52: 220-229.

Bucciarelli E, Blain S, Tréguer P. Iron and manganese in the wake of the Kerguelen Islands (Southern Ocean). Mar Chem 2001; 73: 21-36.

Bustamante P, Cherel Y, Caurant F, Miramand P. Cadmium, copper and zinc in octopuses from Kerguelen Islands, Southern Indian Ocean. Polar Biol 1998; 19: 264-271.

Capelli R, Miganti V, Fiorentino F de Pellegrini R. Mercury and selenium in Adamussium colbecki and Pagothenia bernacchii from the Ross Sea (Antarctica) collected during Italian expeditions 1988-89. Ann Chim 1991; 81: 357-369. 
Cherel Y, Weimerskirch H, Trouvé C. Food and feeding ecology of the neritic-slope forager black-browed albatross and its relationships with commercial fisheries in Kerguelen waters. Mar Ecol Prog Ser 2000; 207: 183-199.

CSHPF (Conseil Supérieur d'Hygiène Publique de France). Plomb, cadmium et mercure dans l'alimentation : évaluation et gestion du risque. Ministère du Travail et des Affaires Sociales (ed). Lavoisier Tec et Doc, Paris, 1995.

Duhamel G, Hureau JC. La situation de la pêche aux Iles Kerguelen en 1981. Pêche Marit 1981; 1238: 272-279.

Gon O, Heemstra PC. Fishes of the Southern Ocean. JLB Smith Institute of Ichthology, Grahamstown, 1990, 462 pp. 12pls.

Guinet C, Cherel Y, Ridoux V, Jouventin P. Consumption of marine resources by seabirds and seals in Crozet and Kerguelen waters: changes in relation to consumer biomass 1962-85. Antarct Sci 1996; 8: 23-30.

Hennig HFKO, Eagle GA, McQuaid CD, Rickett LH. Metal concentrations in Antarctic zooplankton species. In: Siefried WR, Condy PR and Laws RM (eds) Antarctic Nutrient Cycles and Food Webs. Springer-Verlag Berlin, Heidelberg, 1985, p 656-661.

Hellou J, Warren WG, Payne JF, Belkhode S, Lobel P. Heavy metals and other elements in three tissues of cod Gadus morhua from the Northwest Atlantic. Mar Pollut Bull 1992; 24: 452-458.

Honda K, Sahrul M, Hikada H, Tatsukawa R. Organ and tissue distribution of heavy metals, and their growth-related changes in Antarctic fish, Pagothenia borchgrevinki. Agric Biol Chem 1983; 47: 2521-2532.

Hulley PA. Family Myctophidae. In: Gon O \& Heemstra PC (eds) The Fishes of the Southern Ocean. Grahamstown: JLB Smith Institute of Ichthyology, 1990, p146-178. 
Lenihan HS, Oliver JS, Oakden JM, Stephenson MD. Intense and localised benthic marine pollution around McMurdo Station, Antarctica. Mar Pollut Bull 1990; 21: 422-430.

Macdonald CR, Sprague JB. Cadmium in marine invertebrates and arctic cod in the Canadian Arctic. Distribution and ecological implications. Mar Ecol Prog Ser 1988; 47: 17-30.

Marquez M, Vodopivez C, Casaux R, Curtosi A. Metal (Fe, Zn, Mn and Cu) levels in the Antarctic fish Notothenia coriiceps. Polar Biol 1998; 20: 404-408.

Miganti V, Fiorentino F, de Pellegrini R, Capelli R. Bioaccumulation of mercury in the Antarctic bony fish Pagothenia bernacchii. Int J Environ Anal Chem 1994; 55: 197-202.

Miganti V, Capelli R, Fiorentino F, de Pellegrini R, Vacchi M. Variations of mercury and selenium concentrations in Adamussium colbecki and Pagothenia bernacchii from Terra Nova Bay (Antarctica) during a five years period. Int J Environ Anal Chem 1995; 61: 239-248.

Miramand P, Lafaurie M, Fowler SW, Lemaire P, Guary JC, Bentley D. Reproductive cycle and heavy metals in the organs of red mullet, Mullus barbatus (L.), from the northwestern Mediterranean. Sci Tot Environ 1991; 103: 47-56.

de Moreno JEA, Gerpe MS, Moreno VJ, Vodopivez C. Heavy metals in Antarctic organisms. Polar Biol 1997; 17: 131-140.

Petri G, Zauke GP. Trace metal in the crustaceans in the Antarctic Ocean. Ambio 1993; 22: 529-536.

Plancke. Phytoplankton biomass and productivity in the Subtropical Convergence area and shelves of the western Indian subantarctic Islands. In : Llano GA (ed) Adaptations within Antarctic ecosystems. Proceedings of the third SCAR Symposium on Antarctic Biology, Washington DC, Aug 26-30, 1974. Smithsonian Institution, Washington, DC, 1977; pp 51-73.

Rainbow PS. Copper, cadmium and zinc concentrations in oceanic amphipod and euphausiid crustaceans, as a source of heavy metals to pelagic seabirds. Mar Biol 1989; 103: 513-518. 
Ritterhoff J, Zauke GP. Trace metals in field samples of zooplankton from the Fram Strait and the Greenland sea. Sci Tot Environ 1997; 199: 255-270.

Roméo M, Siau Y, Sidoumou Z, Gnassia-Barelli M. Heavy metal distribution in different fish species from the Mauritanian coast. Sci Tot Environ 1999; 232: 169-175.

Sanchez-Hernandez JC. Trace element contamination in Antarctic ecosystems. Rev Environ Contam Toxicol 2000; 166: 83-127.

Santovito G, Irato P, Piccini E, Albergoni V. Relationship between metallothionein and metal contents in red-blooded and white-blooded Antarctic teleosts. Polar Biol 2000; 23: 383-391.

Szefer P, Czarnowski W, Pempkowiak J, Holm E. Mercury and major essential elements in seals, penguins, and other representative fauna of the Antarctic. Arch Environ Contam Toxicol 1993; 25: 422-427.

Thompson DR. Metal levels in marine invertebrates. In:Furness RW and Rainbow PS (eds). Heavy metals in the marine environment. CRC Press, Boca Raton, 1990, p143-182.

Zauke GP, Savinov VM, Ritterhoff J, Savinova T. Heavy metals in fish from the Barents Sea (summer 1994). Sci Tot Environ 1999; 227: 161-173. 
Table 1. Characteristics of the fish samples, together with the water content in the tissues and organs allowing conversion of dry wt to wet wt metal concentrations.

\begin{tabular}{|c|c|c|c|c|c|c|c|c|}
\hline \multirow{2}{*}{$\begin{array}{l}\text { Family } \\
\text { Species }\end{array}$} & \multirow[t]{2}{*}{ Localisation } & \multirow[t]{2}{*}{$\begin{array}{l}\text { Sample } \\
\text { size }\end{array}$} & \multirow{2}{*}{$\begin{array}{l}\text { Length } \\
(\mathrm{mm})\end{array}$} & \multirow{2}{*}{$\begin{array}{l}\text { Fresh } \\
\text { weight } \\
(\mathrm{g})\end{array}$} & \multirow[t]{2}{*}{ Sex } & \multicolumn{3}{|c|}{$\begin{array}{c}\text { Water content } \\
(\%)\end{array}$} \\
\hline & & & & & & Liver & Kidney & Muscle \\
\hline \multicolumn{9}{|l|}{ Pelagic fish } \\
\hline \multicolumn{9}{|l|}{ Gempylidae } \\
\hline Paradiplospinus gracilis & Oceanic zone & 1 & 370 & 67 & 0 & 55 & 78 & 71 \\
\hline \multicolumn{9}{|l|}{ Myctophidae } \\
\hline Gymnoscopelus nicholsi & Oceanic zone & 4 & $144 \pm 15$ & $31 \pm 8$ & 4 ㅇ & $42 \pm 6$ & $45 \pm 11$ & $62 \pm 2$ \\
\hline Gymnoscopelus piabilis & Oceanic zone & 5 & $151 \pm 11$ & $37 \pm 6$ & 5 우 & $56 \pm 8$ & $48 \pm 15$ & $76 \pm 3$ \\
\hline \multicolumn{9}{|l|}{ Benthic fish } \\
\hline Champsocephalus gunnari & Kerguelen shelf & 5 & $314 \pm 13$ & $202 \pm 34$ & $1 \mathrm{o}^{\lambda}, 4$ 우 & $73 \pm 2$ & $73 \pm 5$ & $76 \pm 2$ \\
\hline Channichthys rhinoceratus & Kerguelen shelf & 5 & $344 \pm 52$ & $435 \pm 150$ & $2 \mathrm{O}^{\lambda}, 3$ 우 & $75 \pm 4$ & $83 \pm 2$ & $81 \pm 3$ \\
\hline \multicolumn{9}{|l|}{ Nototheniidae } \\
\hline Paranotothenia magellanica & Morbihan bay & 5 & $157 \pm 8$ & $92 \pm 17$ & $2 \mathrm{O}^{\lambda}, 3$ ㅇ & $77 \pm 2$ & $81 \pm 2$ & $78 \pm 0$ \\
\hline Notothenia rossii & Morbihan bay & 5 & $237 \pm 41$ & $300 \pm 135$ & $2 \mathrm{O}^{\lambda}, 3$ ㅇ & $73 \pm 4$ & $81 \pm 1$ & $80 \pm 1$ \\
\hline Lepidonotothen squamifrons & Kerguelen shelf & 5 & $284 \pm 29$ & $279 \pm 90$ & $3 \widehat{0}, 2$ ㅇ & $71 \pm 8$ & $78 \pm 4$ & $76 \pm 2$ \\
\hline
\end{tabular}


Table 2. Mean \pm SD and range of the metal concentrations ( $\mu \mathrm{g}^{-g^{-1}}$ dry wt.) in the liver of benthic and pelagic fish from the Kerguelen Island waters.

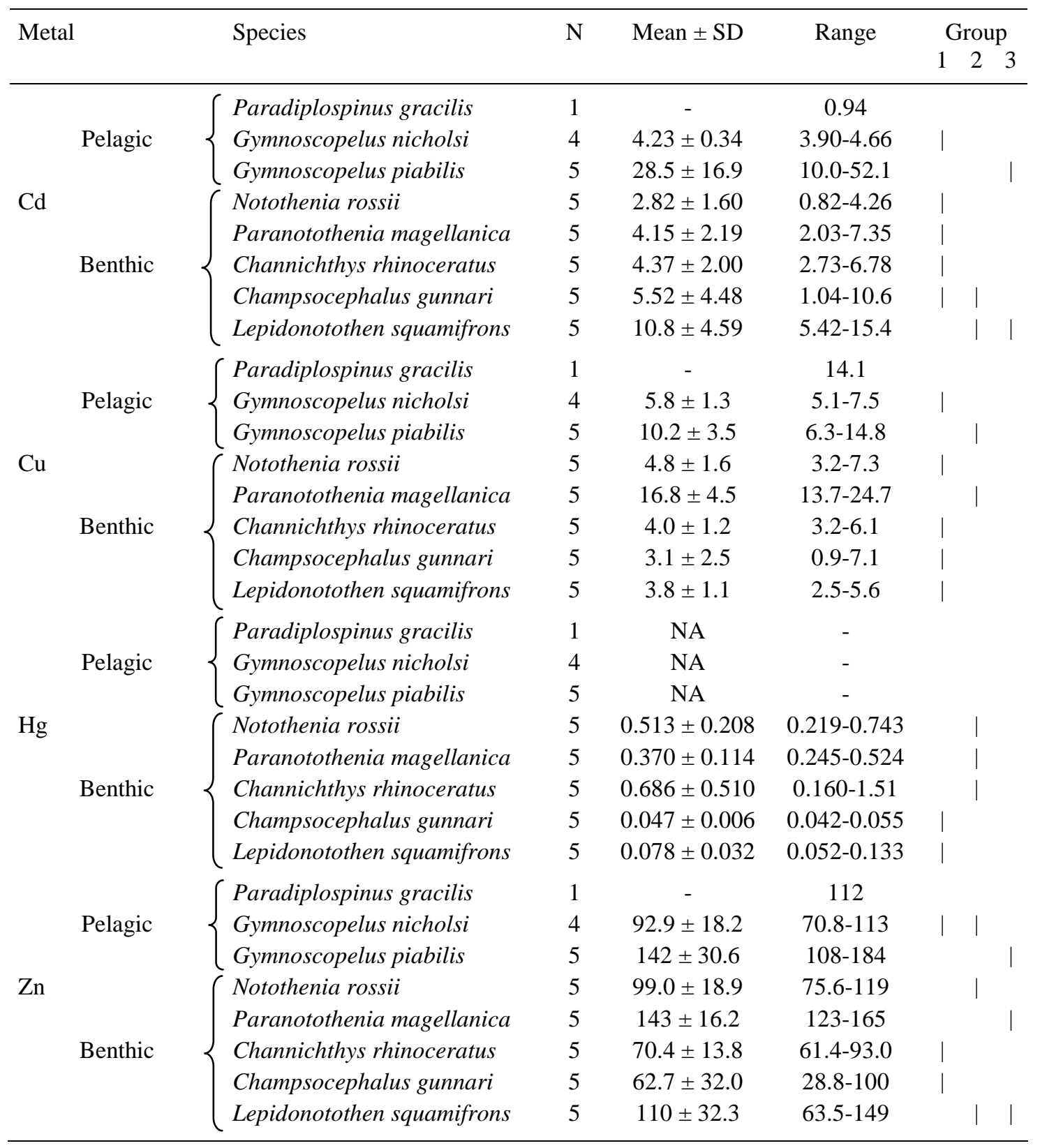

$\mathrm{N}$, independent samples. NA : not analysed. Bars $(\mid)$ indicates groups identified by non parametric tests. 
Table 3. Mean \pm SD and range of the metal concentrations ( $\mu \mathrm{g} \cdot \mathrm{g}^{-1}$ dry wt.) in the kidney of benthic and pelagic fish from the Kerguelen Island waters.

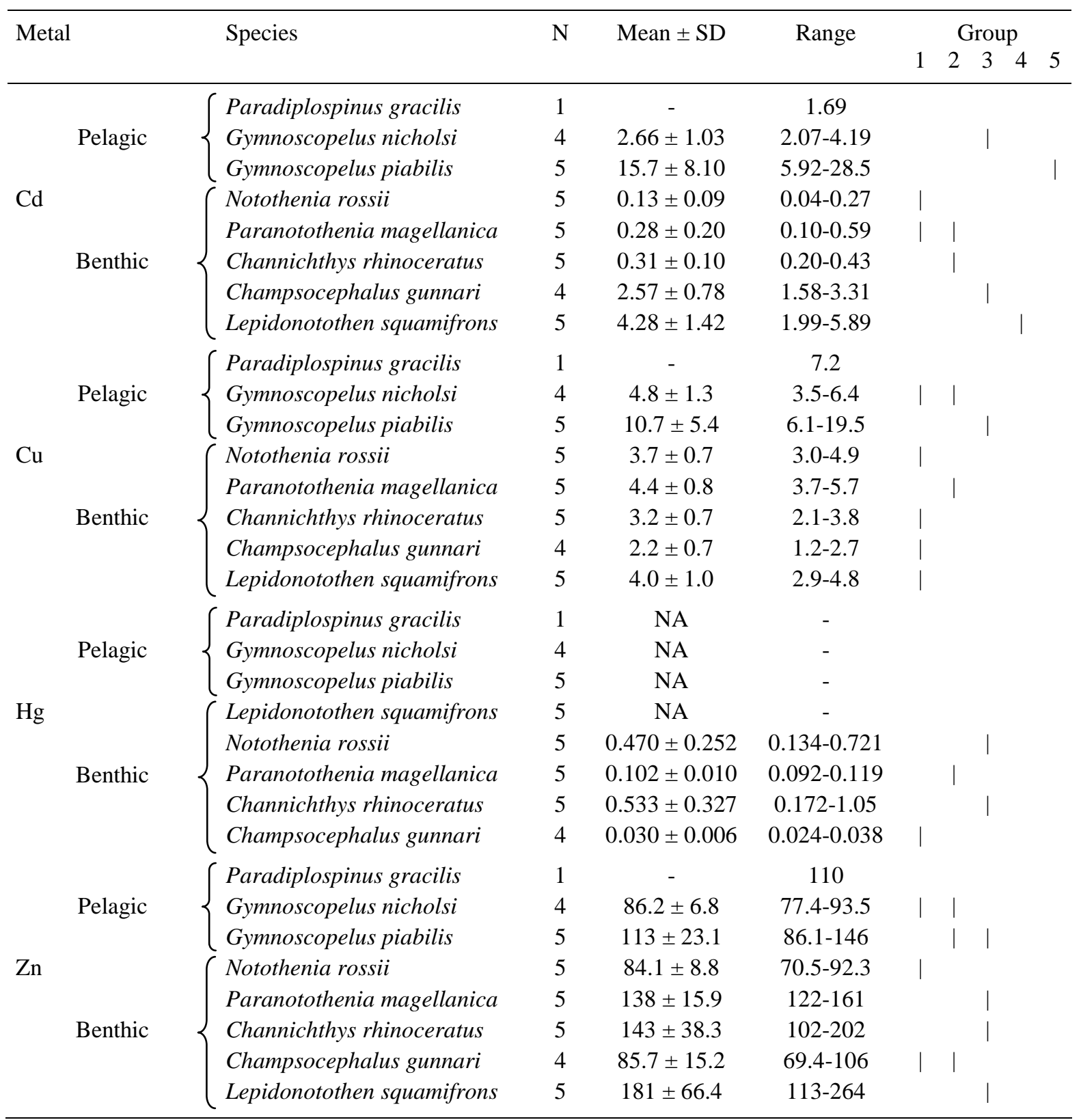

$\mathrm{N}$, independent samples. NA : not analysed. Bars $(\mid)$ indicates groups identified by non parametric tests. 
Table 4. Mean \pm SD and range of the metal concentrations ( $\mu \mathrm{g} \cdot \mathrm{g}^{-1}$ dry wt.) in the muscle of benthic and pelagic fish from the Kerguelen Island waters.

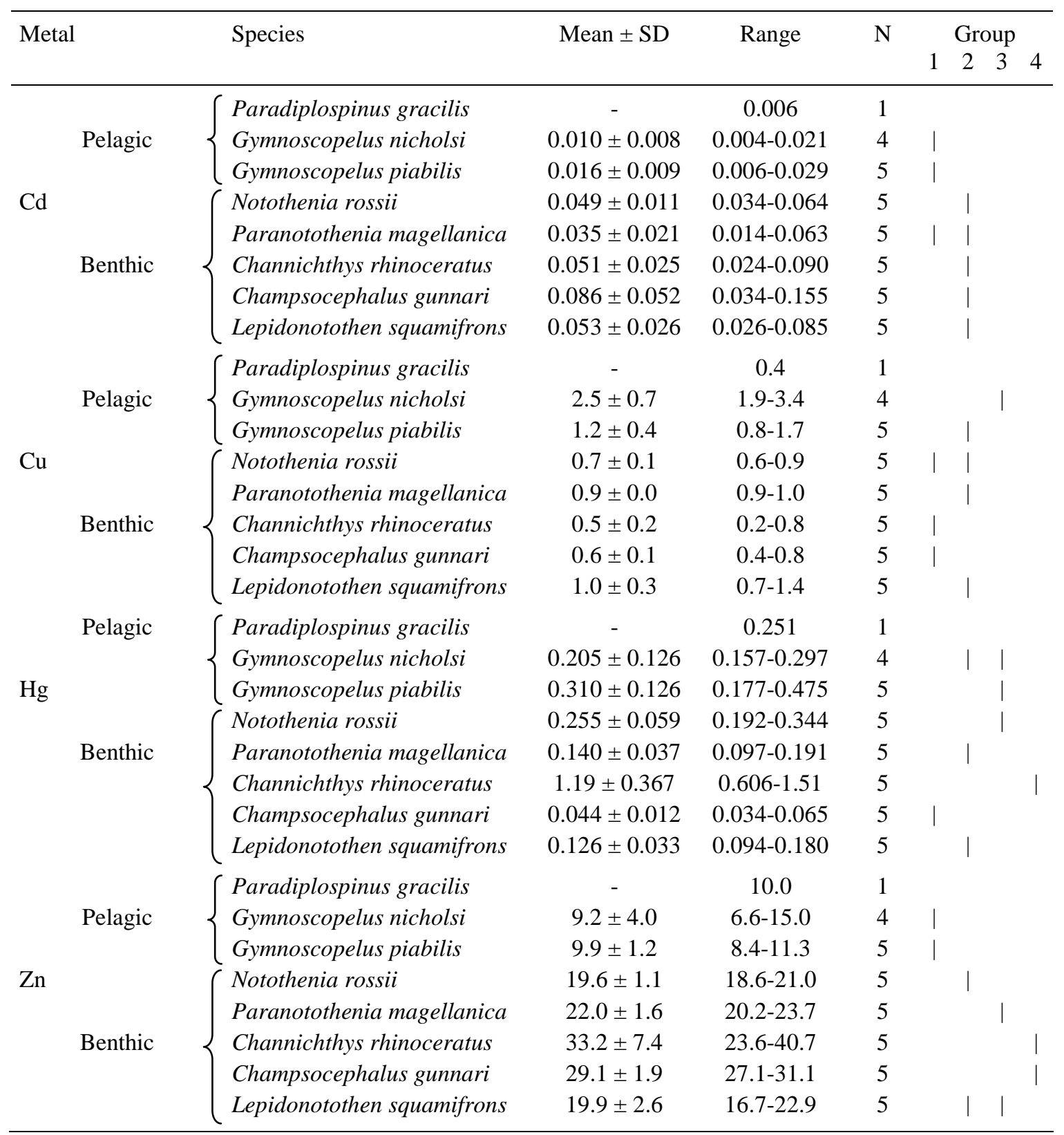

$\mathrm{N}$, independent samples. Bars $(\mid)$ indicates groups identified by non parametric tests. 
Table 5. Distribution of the metals in benthic and pelagic fish from the Kerguelen Islands waters. Mean $\% \pm$ SD referred to the fresh weight of organs and tissues.

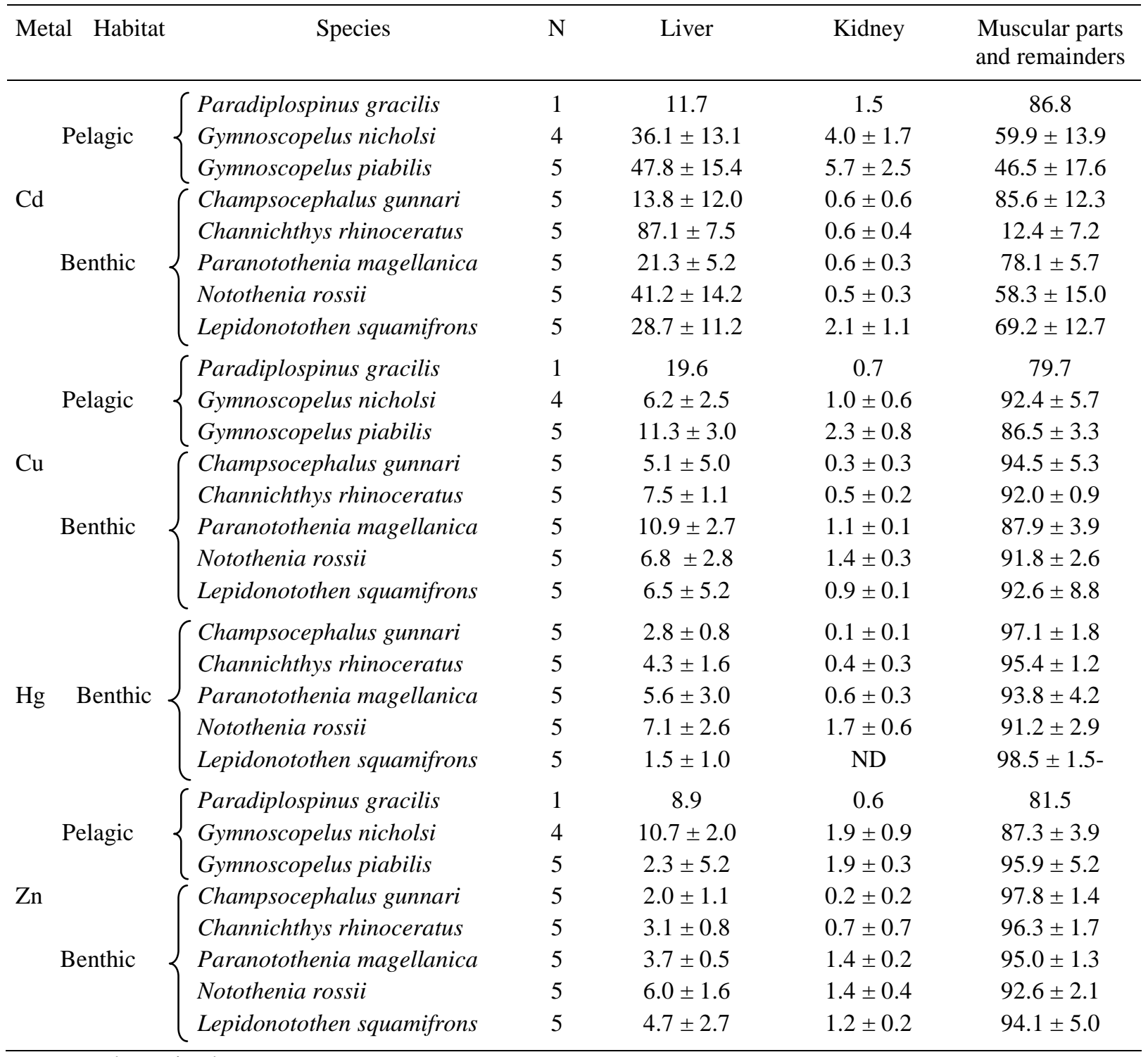

ND : not determined. 
Table 6. Metal concentrations in the liver of fish from the Antarctic Ocean. Values represent the ranges or mean \pm SD, expressed as $\mu$ g. $\mathrm{g}^{-1} \mathrm{dwt}$ or wwt.

\begin{tabular}{|c|c|c|c|c|c|c|c|c|}
\hline Species & Sample area & $\mathrm{N}$ & $\mathrm{Cd}$ & $\mathrm{Cu}$ & $\mathrm{Hg}$ & $\mathrm{Zn}$ & Basis & Reference \\
\hline Chaenocephalus aceratus & Antarctic peninsula & 4 & $1.01-1.25$ & $3.3-5.4$ & - & $87.7-106.0$ & dwt & Szefer et al. (1993) \\
\hline Chionodraco hamatus & Terra Nova Bay & 20 & $1.02-14.53$ & - & - & - & dwt & Bargagli et al. (1996) \\
\hline " & $"$ & 18 & - & - & $0.02-0.44$ & - & dwt & Bargagli et al. (1998) \\
\hline$"$ & $"$ & 16 & $0.99 \pm 0.97$ & $0.85 \pm 0.70$ & - & $18.70 \pm 5.13$ & dwt & Santovito et al. (2000) \\
\hline Cryodraco antarcticus & " & 6 & $0.86-4.25$ & - & - & - & dwt & Bargagli et al. (1996) \\
\hline Notothenia coriiceps (male) & South Shetland Islands & 9 & - & $2.46 \pm 0.84$ & - & $29.55 \pm 8.64$ & wwt & Marquez et al (1998) \\
\hline$" \quad$ (female) & $"$ & 10 & - & $1.58 \pm 0.38$ & - & $23.62 \pm 2.20$ & wwt & Marquez et al (1998) \\
\hline Pagothenia borchgrevinski & Syowa Station & 18 & $0.30-2.46$ & $0.92-5.88$ & $0.005-0.026$ & 22.4-34.2 & wwt & Honda et al. (1983) \\
\hline Trematomus bernacchii & Terra Nova Bay & 18 & $3.36-21.60$ & - & - & - & dwt & Bargagli et al. (1996) \\
\hline$"$ & $"$ & 11 & - & - & $0.10-0.82$ & - & dwt & Bargagli et al. (1998) \\
\hline$"$ & $"$ & 15 & $7.30 \pm 5.61$ & $5.19 \pm 3.03$ & - & $44.35 \pm 24.72$ & dwt & Santovito et al. (2000) \\
\hline Trematomus hansoni & $"$ & 18 & $5.09-16.42$ & - & - & - & dwt & Bargagli et al. (1996) \\
\hline " & $"$ & 18 & - & - & $0.08-0.69$ & - & dwt & Bargagli et al. (1998) \\
\hline Trematomus newnesi & $"$ & 8 & $0.98-5.75$ & - & - & - & dwt & Bargagli et al. (1996) \\
\hline " & $"$ & 7 & - & - & $0.09-0.28$ & - & dwt & Bargagli et al. (1998) \\
\hline " & Cinder cones & - & $12 \pm 4$ & $14 \pm 2$ & - & $127 \pm 25$ & wwt & " \\
\hline
\end{tabular}


Table 7. Metal concentrations in the kidney of fish from the Antarctic Ocean. Values represent the ranges or mean expressed as $\mu \mathrm{g} . \mathrm{g}^{-1} \mathrm{dwt}$ or wwt.

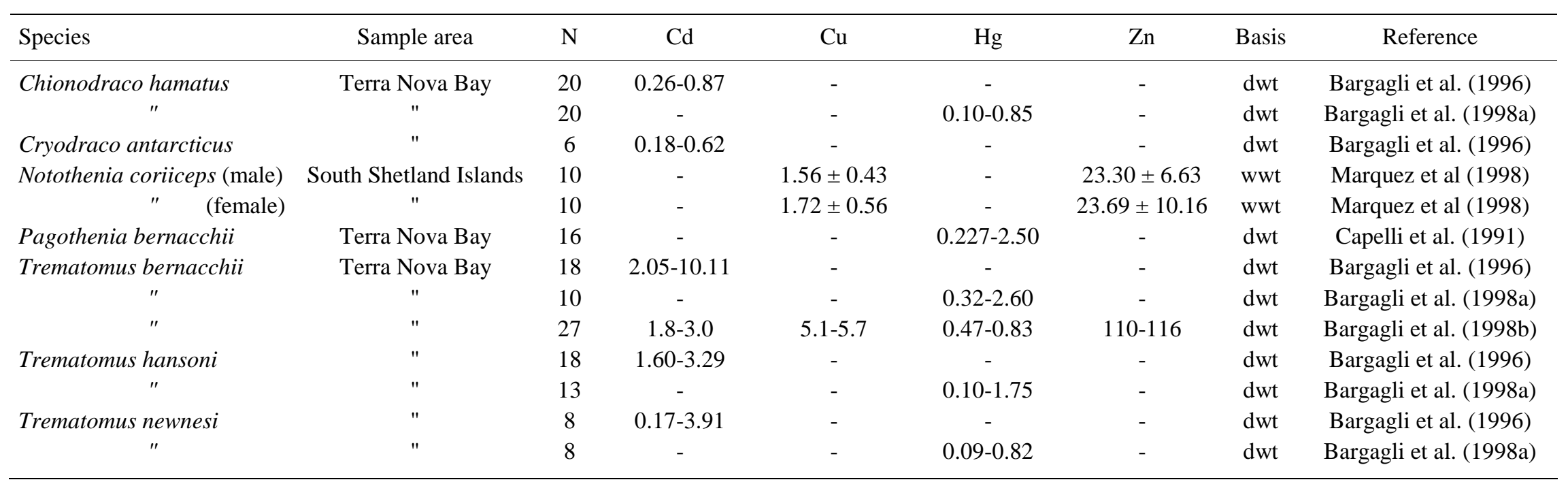


Table 8. Metal concentrations in the muscle of fish from the Antarctic Ocean. Values represent the ranges or mean expressed as $\mu \mathrm{g} . \mathrm{g}^{-1} \mathrm{dwt}$ or wwt.

\begin{tabular}{|c|c|c|c|c|c|c|c|c|}
\hline Species & Sample area & $\mathrm{N}$ & $\mathrm{Cd}$ & $\mathrm{Cu}$ & $\mathrm{Hg}$ & $\mathrm{Zn}$ & Basis & Reference \\
\hline Chionodraco hamatus & Terra Nova Bay & 20 & $0.01-0.03$ & - & - & - & dwt & Bargagli et al. (1996) \\
\hline " & " & 7 & - & - & $0.01-0.92$ & - & dwt & Bargagli et al. (1998a) \\
\hline$"$ & $"$ & 10 & $0.97 \pm 0.47$ & $0.70 \pm 0.67$ & - & $6.27 \pm 3.73$ & dwt & Santovito et al. (2000) \\
\hline Chaenocephalus aceratus & Antarctic peninsula & 3 & $0.05-0.13$ & $1.0-2.0$ & - & $28.6-35.5$ & dwt & Szefer et al. (1993) \\
\hline Cryodraco antarcticus & Terra Nova Bay & 6 & $0.01-0.06$ & - & - & - & dwt & Bargagli et al. (1996) \\
\hline Notothenia coriiceps (male) & South Shetland Islands & 10 & - & $1.00 \pm 0.34$ & - & $4.77 \pm 1.08$ & wwt & Marquez et al (1998) \\
\hline " & South Orkney Islands & 11 & $<0.05$ & $0.04-0.50$ & $0.01-0.10$ & $1.00-6.70$ & wwt & de Moreno et al (1997) \\
\hline$" \quad$ (female) & South Shetland Islands & 10 & - & $4.79 \pm 0.81$ & - & $1.01 \pm 0.62$ & wwt & Marquez et al (1998) \\
\hline$"$ & South Orkney Islands & 17 & $<0.05$ & $0.05-0.40$ & $0.01-0.09$ & $2.00-5.40$ & wwt & de Moreno et al (1997) \\
\hline Notothenia gibberifrons & Antarctica & 3 & $0.02-0.04$ & $0.71-0.98$ & - & $20.7-24.2$ & dwt & Szefer et al. (1993) \\
\hline Pagothenia borchgrevinski & Syowa Station & 22 & $0.01-0.04$ & $0.17-1.39$ & $0.002-0.009$ & $4.27-8.15$ & wwt & Honda et al. (1983) \\
\hline Pagothenia bernacchii & Terra Nova Bay & 18 & - & - & $0.230-0.990$ & - & dwt & Minganti et al (1994) \\
\hline Trematomus bernacchii & Terra Nova Bay & 18 & $0.01-0.08$ & - & - & - & dwt & Bargagli et al. (1996) \\
\hline$"$ & $"$ & 12 & - & - & $0.17-1.79$ & - & dwt & Bargagli et al. (1998a) \\
\hline$"$ & " & 27 & $0.03-0.05$ & $1.9-2.5$ & $0.49-0.74$ & $22.8-23.6$ & dwt & Bargagli et al. (1998b) \\
\hline$"$ & $"$ & 10 & $0.74 \pm 0.48$ & $0.32 \pm 0.23$ & - & $2.88 \pm 1.89$ & dwt & Santovito et al. (2000) \\
\hline Trematomus hansoni & " & 18 & $0.01-0.05$ & - & - & - & dwt & Bargagli et al. (1996) \\
\hline " & $"$ & 15 & - & - & $0.11-1.08$ & - & dwt & Bargagli et al. (1998a) \\
\hline Trematomus newnesi & $"$ & 8 & $0.02-0.05$ & - & - & - & dwt & Bargagli et al. (1996) \\
\hline$"$ & " & 7 & - & - & $0.09-0.82$ & - & dwt & Bargagli et al. (1998a) \\
\hline Trematomus sp. & Winter Quarters Bay & - & $0.1-0.2$ & $0.1-0.3$ & - & $0.4-25$ & wwt & Lenihan et al. (1990) \\
\hline " & Cinder cones & - & 0.2 & $0.9 \pm 0.8$ & - & $41 \pm 13$ & wwt & " \\
\hline
\end{tabular}

